\title{
Constantin Catrina - a life in the service of the Romanian music
}

\author{
IRINA ZAMFIRA DĂNILĂ \\ "George Enescu" National University of Arts Iasi \\ ROMÂNIA*
}

\begin{abstract}
A complex personality, with multifarious concerns in research as well as in composition, Constantin Catrina (1933-2013) was active as a folklorist, historian, musicologist, Byzantinologist, composer; he dedicated his entire life to the research of the Romanian music, viewed in all its manifold manifestations: folklore music, Orthodox church music of the Byzantine tradition as well as lay music. His investigations were directed mainly towards the area of Brasov and its surroundings. He diligently studied documents about the musical life of the city in archives and libraries, discovered interesting information about the cultural personalities of this old Transylvanian city, with rich cultural traditions and diverse influences. He also managed to reveal their connections with other cultural centres in Romania. He was a pioneer in the field of Byzantinology, filling a space left empty in the history of Byzantine music by emphasizing the activity of an important centre of church music teaching and education in central Transylvania - the School of "Saint Nicholas" Church in Scheii Brasovului between the 15th and 20th centuries. In terms of folklore research, he investigated the areas related to Brasov and collected a rich ethnographic, literary and musical material which he published in reputable collections. In all three lines of activity, he wrote and published an impressive number of articles in the local and specialised national press, thus proving to have a genuine passion for research and for the dissemination of its results to the specialists and the general public.
\end{abstract}

Keywords: Constantin Catrina, Brasov, historian, musicologist, folklorist, byzantinologist

\section{Introduction}

I had the opportunity of meeting researcher Constantin Catrina on the occasion of a research project in which I participated in 2007. I was a young assistant and $\mathrm{PhD}$ student then, at the beginning of my career, especially with regard to scientific research. At the beginning of the documentation stage in the project I had the opportunity of getting in contact with a substantial collection of musical manuscripts with psalm chanting notation, i.e. the manuscript at the Varatec Monastery, Neamt county. Also, I was first introduced to the process of cataloguing such documents, under the guidance of two distinguished specialists: Priest Florin Bucescu, a reputed folklorist and Byzantinologist of

*dzamfira@yahoo.com 
Iasi, and the musicologist and folklorist Constantin Catrina, of Brasov. Patiently and competently, always good natured, they introduced me to the fascinating study of the manuscripts of church music, which has, ever since, remained a standing interest ${ }^{1}$.

\section{Constantin Catrina - Biographical Data}

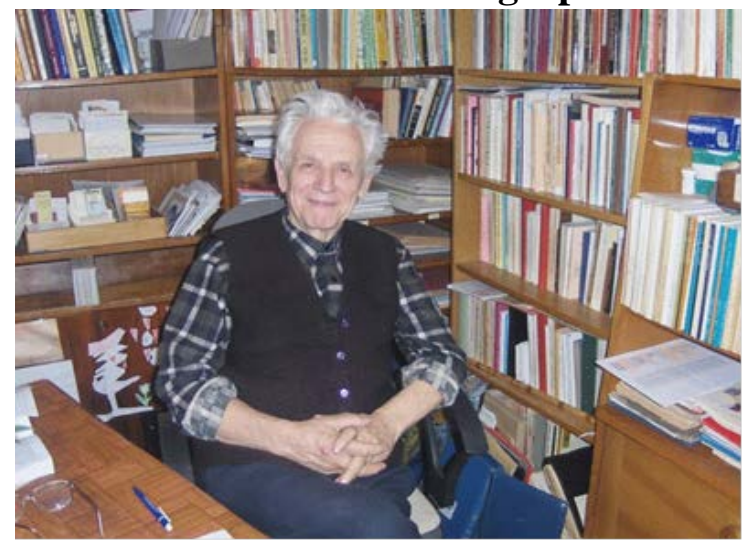

Fig. 1 Constantin Catrina (1933-2013) in his study

A native of the Oltenia region, Constantin Catrina (Fig. 1) he was born in 1933 in the village of Got, Olt county, in the family of George and Nicolița Catrina, hard-working broadminded peasants, who encouraged and supported him to study. Constantin proved to be intelligent and to have a great musical sensitivity; he attended primary school in his native village, and then he attended the theological Seminary of Craiova and Mofleni, Dolj county. The change of the political regime occurring after World War II prevented the young seminary graduate from continuing his theological career and made him redirect his interest towards music. Certainly, the theological and musical education he had acquired at the seminary had a favourable influence on him, but according to his own confessions, his talents were still in a dormant state, in expectation of more favourable times. He then attended the secondary School of music in Craiova, which then graduated in Brașov in 1954, where destiny seemed to guide him. After completing his military service in the military brassbands at Dorohoi and Orastie (Deaconu, 2008, p. 13), which helped him broaden his musical experience, he started his professional activity in traditional music, of which he was fond and which he knew from childhood among the peasants, in

\footnotetext{
${ }^{1}$ Such a subjective introduction reminiscent of memoirs, may seem unusual, especially at the beginning of a scientific article. However, I consider it to be my duty to acknowledge my connection with Mr. Constantin Catrina, characterised by respect and affection, since his moral and professional stature as a genuine musicologist has contributed to my own development and has been a model to follow. I should also add here that the "history" of his last book, dedicated to the celebration of his 80th anniversary, has made a deep impression on me. Mr. Catrina patiently began to write it as early as 2011 with his well-known concern for detail and skills; sadly, however, he didn't live to enjoy this beautiful culmination of all his activities in the musical domain, as he was moved from "the world of yearnings to that where there are no yearnings" just a few months before his birthday, to take place in November 2013. This is one of the - personal, subjective - reasons that made me choose to write a portrait of this distinguished musician - Constantin Catrina.
} 
the countryside. He was, successively, a councillor, the conductor of the Culture House choir and of the brassband in Rupea (Brasov county), the secretary and inspector to the Department of Education and Culture of the District of Rupea. During 1960-1963 he continued his musical studies at university level, at the "Ciprian Porumbescu" Conservatory of Bucharest, but in fact graduated at the "Gheorghe Dima" Conservatory in Cluj Napoca, after a six years' break due to his professional activity in Brasov, as inspector methodologist and teacher (Deaconu, 2008, p. 14). Due to his inquisitive spirit and tireless passion for everything that means tradition, he had many initiatives in researching folklore, setting up a folklore research and folklore collection sub-branch at Rupea, and a research laboratory in Brasov to study the issues of mass culture; he made himself remarked for publishing on folklore, but also as a composer. In recognition of his invaluable activities as a musicologist and composer, in 1977, Constantin Catrina was made a member of the Union of Composers and Musicologists of Romania (Deaconu, 2008, p. 15).

In the years to follow, Constantine Catrina strengthened his position as art manager and promoter of the cultural life of the city of Brasov, and continued his tireless and passionate activity as a researcher and collector of folk music. After the events in December 1989, along with the changes brought about by the fall of the totalitarian regime, important changes in all areas occur in Brasov, including changes in higher education. The University of Braşov, established in 1971 as a merger of the Polytechnic Institute with the Pedagogical Institute, will be renamed as the "Transylvania" University in 1991 and will significantly increase the number of domains by adding other domains, including that of musical studies, which existed as early as 1971, but only as a department of music. Between 1990-2003, Constantin Catrina will teach the course of Musical Folklore at the Faculty of Music established in 1991, as an associated Assistant Professor, PhD. He defended his doctoral thesis in 2000 on an interesting topic in Byzantinology, The Music of Byzantine tradition in Scheii Brasovului - the school and the teachers; his $\mathrm{PhD}$ coordinator was the reputed researcher and paleographer, professor archdeacon Sebastian Barbu-Bucur (Deaconu, 2008, p. 17).

In the years that followed his retirement from teaching he continued his activity as a celebration of his entire life, dedicated to historiography, research, folklore and musical Byzantinology, as well as cultural media in Brasov, as we will detail in what follows.

\section{Musical historiography and musicology - Constantin Catrina's fields of outstanding achievement.}

As early as his first years of professional activity, Constantin Catrina began to teach himself the methods of scientific research in the field of folklore and historiography. He had a special talent in discovering archive documents, 
he improved constantly over time and became a reputed historiographer, well known especially in the Brasov area, but also at national level. His eagerness to study old documents was stimulated by the cooperation with Gheorghe N., teacher and priest Dumitrescu-Bistrița (1895-1992), acclaimed folklorist, founder of the journal of folklore "Izvorașul". This journal appeared in the period 1919-1940; it addressed a wide range of information in the field of folklore - musical, literary, ethnological; the focus was especially on musical folklore, and on the ornaments in folk music (Bârlea, 1974, p. 401). The journal was particularly appreciated by specialists and it represented a model designed with the very aim of publicising at a national level the transcripts of traditional music, of processing choir folklore, so much appreciated by the amateur choirs from both the rural and urban areas, as well as some valuable papers covering general folklore issues. Information was provided by the author but also by the many collaborators of the magazine, who were "the most agile and inquisitive minds of the time: priests and teachers, pupils and students, farmers and housewives, clerks, with the aim of putting forward the everlasting «reservoir» of the material and spiritual culture all across unified Romania.” (Catrina, 2009, p. 174)

Grateful to folklorist priest Gheorghe N. Dumitrescu-Bistrița, Constantin Catrina will dedicate a book to his mentor during the years of youth and professional maturity, entitled Priest Gh. N. Dumitrescu-Bistrița and the magazine "Izvoraşul" (2009). The work is based on the novel correspondence, received from Gheorghe N. Dumitrescu in the 40 years in which they collaborated, as well as on studies, articles and communications that Constantin Catrina developed about the work of the distinguished folklorist of Mehedinti, especially after 1990. The large number of letters is impressive for their great documentary value on account of the information related to the activity in the field of folklore research, and especially on account of the way in which they outline the professional and human profiles of the two folklorists: a deep mutual respect, elevated ideas, a passion for the values of the Romanian folklore, the love of the people and of their motherland. Priest Gh. N. Dumitrescu's role as a mentor is emphasized by the correspondence published; he identified and appreciated his disciple's genuine talent in discovering and exploiting documents in archives and in collecting folklore in field research activities; he encouraged his disciple and also served as a necessary model to any researcher who is just beginning his career.

One of Constantin Catrina's key contributions in musicology is his book Studies and Documents on Romanian music, published in two volumes (1986, 1994 respectively). Relying on painstaking research carried out in library archives, Constantin Catrina tackles the personalities of the Romanian music, especially those that were linked to the musical life of Brassov city. For example, the second volume presents novel aspects of the musical work of 
composers Gheorghe Dima, Sabin V. Drăgoi, Paul Richter and Tiberiu Brediceanu. He also dedicated three articles to George Enescu, in which details of the great conductor's journeys to Brasov in the interwar period are presented for the first time. An ample chapter is dedicated to documents in various archives, namely to the collection of texts and correspondence belonging to historian Mihail Gr. Poslușnicu, in the Library of the Romanian Academy in Bucharest. The importance of publishing such documents results - as shown by Constantin Catrina - from the fact that "they shed light on aspects related to the history of music education, some initiatives, ideas and points of view on the phenomenology of Romanian artistic life $[\ldots .$.$] as well as some details related to$ many of our musicians' creation and performance.” (Catrina, 1994, p. 150). In the last chapter of the book, entitled "The heritage value of manuscripts, music sheets and music books" he resorts once more to old documents from libraries, as well as from the print media of the 19th century. Thus, relying on arguments from archives, the author first shows the importance of the patriotic songs of 1848, which was preserved in an unpublished manuscript discovered in the old town of Rupea, near Brasov (Catrina, 1994, p. 208). Then, in the musical paper Scores edited by "Astra", he emphasizes the role of the "Astra" cultural association of Brasov in printing and disseminating valuable Romanian music sheets, a heritage that has contributed to strengthening the national identity in the years before the Great Unification of 1918 (Tiberiu Brediceanu - The musical ethnographic poem Transylvania, Banat, Crişana and Maramureş in the clothes, dancing and songs, 1905 and The evening social gathering - the image of the people, 1908) (Catrina, 1994, p. 217). Finally, in the last article of the chapter mentioned, Contributions to disseminating books on Romanian old music, Constantin Catrina adds new information on the circulation of the volumes by Macarie the Hieromonk in the area of Brasov and Sibiu, thus emphasizing once again the important role that the publishing of the first theoretical books and repertoire by Macarie the Hieromonk had in implementing the Chrysantean reform in the Romanian Principalities. To conclude, we emphasize once again the value of the studies and papers in the volume under discussion, which follows from the use of extremely reliable resources, found in archives - books and old documents, the written press.

The book The Music and Musicians of the City, published in two volumes, is of particular interest for the history of Romanian music, in general, and of the music-related personalities in the Brasov area, in particular. The first volume was published in 2010; in the first three sections, new details are added to issues related to the moments when the activity of composers Ciprian Porumbescu, Timotei Popovici and Norbert Nori came into contact with the musical life of Brașov. The author also includes unpublished pages of correspondence by Gheorghe Dima (letters from prison) and Paul Richter, as well as by other Transylvanian musicians, outlining or filling in the larger 
picture of the musical and artistic life of the city of Brasov. The third section, "Always on a genius of Romanian music: George Enescu", resumes the memorable moments of the great composer's concerts in Brasov; the fourth section, which discusses journalistic and musicological issues, includes a few interviews in which Constantin Catrina talked to reputed female-musicians from Brasov, women with excellent artistic results at national and international level: teacher and conductor Elena Criveanu, the opera manager Carmen Dobrescu, organ player Lidia Sumnevici and young composer Ana Szilágyi. The cleverly devised questions manage to elicit interesting responses and to outline the balanced spiritual and professional portraits of the talented artists. The paper ends with the review of three volumes, the first two of which are dedicated to two personalities of Brasov, namely conductor and organist Viktor Bickerich and conductor Dinu Niculescu, who greatly contributed to heightening the prestige of the symphonic orchestra and generally of the musical activity in Brașov. The third volume reviewed, whose author is Vasile Tomescu, one of the seniors of Romanian musicology, is particularly interesting, as its theme is a creative period less addressed in the specialised literature - Renaissance - as manifested in the Romanian music. The issue addressed in the volume is masterfully and meticulously presented by the musicologist; his discourse is elevated, yet accessible.

\section{The music of Byzantine tradition. Șcheii Brașovului (a locality close to Brasov) or the historiographic method masterfully applied to Byzantine music}

Constantin Catrina established his reputation in the field of musical Byzantinology towards the end of his career, when he had reached full maturity and acquired ample professional experience. As mentioned in the second section of this paper, the way the musicologist prepared to be admitted to the seminar had an important role in his spiritual development, but also in terms of acquiring in-depth knowledge of the Orthodox cult music of Byzantine tradition. The knowledge and skills acquired in this area remained dormant during the period of the communist regime and were activated and used much later, after 1990, when Constantine Catrina found favourable conditions to do research in this valuable area of Romanian music.

One of the noteworthy achievements in this respect was his doctoral thesis, The Music of Byzantine tradition. Șcheii Braşovului, defended in 2000 at the National University of Music in Bucharest, coordinated by Byzantinologist Priest Sebastian Barbu-Bucur. The thesis was appreciated by the specialists as early as the time when it was published (Braşov, Arania Publishing House, 2001). This is, for example, an assessment by his very $\mathrm{PhD}$ coordinator, S. B. Bucur: "the thesis written by Constantin Catrina is exceptional, as the $\mathrm{PhD}$ candidate is himself an exceptional researcher, for over 
forty years. [...] For a long period, his work focused on researching the manifestation of this music (15th-20th century), the age, name and activity of church singers natives of the place, the evolution and profile of the school, the cultural and religious events sponsored by the two institutions mentioned (St. Nicholas Church and the School from Șcheii Brașovului; the author identified new and significant directions for musicological research, which he reported in a large number of pages that also contained illustrations, comparative morphological analyses, etc. To this end, Constantin Catrina read a huge number of bibliographical resources [...], as well as numerous archive documents and musical manuscripts mainly from the library of the Museum of the "Sf. Nicholas" church in Scheii Brasovului or from various other documents in the archives and special collections in the country" (Catrina, 2001, pp. 5-6).

Researcher Constantin Catrina's volume The music of Byzantine tradition. S,cheii Brașovului mainly focuses on "the evolution of the educational institution (in Scheii Brasovului, author's note) and to the degree to which it was involved in cult music" (Catrina, 2001, p. 9); it is organized in six parts which follow its development chronologically. The researcher discovers and analyzes old documents, mainly from the archive of the Library of the Museum of "St. Nicholas" Church from Schei - attested as early as 1495, but also from the National Archives in Brasov, and corroborates the results; the researcher thus manages to outline a history of the musical and theological school in Scheii Brasovului, pointing out the significant moments of its development. The first timid manifestations of theological and musical education date from the 15-16th centuries; the early years are linked with the introduction and the development of the printing press, especially in the 17th 18th centuries; cult books purchased by the church of Şchei and the church singers were instrumental in this process, as they improved in the study of the method to perform psaltic music, mainly in the Romanian Principalities. The important role of the Duma family of scholars is emphasized, from among which Ioan sin Radului Duma Braşoveanu (John's son Radu Duma from Brasov) stand out; the latter was a teacher and singer at the church of Şchei and the author of the manuscript Psaltichie rumănească (1751). To compile this important musical document, Ioan Duma draws inspiration from the eponymous manuscript produced in 1713 by the Romanian protopsaltis Filothei sin Agăi Jipei, a teacher of the school within the Metropolitan church in Bucharest; this demonstrates the strong ties between the Orthodox Church in the centre of Transylvania with the church in T,ara Românească, and especially the existence of a unified repertoire and set of worship practices. These links will be maintained along the 19th century; regarding church music, this century was influenced by the implementation of the Chrysanthean reform in the Orthodox cult of the Romanian Principalities. Constantin Catrina's contribution 
can be seen in the description of this period, as he sketched portraits of the musicians who were involved in the reformation process in the Brasov area. Interesting information is summarized about Anton Pann, who was a teacher and main church singer with the church of Şchei for a short while; however, he held an important role in the formation of teachers here. Protosinghelos Varlaam Barancescu's (1808-1894) activity as "a cantor, a creator of Byzantine music, a poet and an exceptional orator" is presented briefly (Catrina, 2001, p. 70); for a decade the Protosinghelos was a main church singer and taught psaltic music at the School within the Church in Scheii Brasovului. Church singer George Ucenescu (1828-1896), a disciple of Anton Pann and a teacher at the same school, is also given an interesting and detailed portrait. Littleknown or even unpublished aspects of this valued musician's activity are highlighted. With regard to teaching, the manuscript Tractatu teoreticupracticu de musica eclesiastică grecească orientală is briefly presented; it contains a compact grammar and a collection of psalm chants intended for the students and includes all the eight modes of the Byzantine Oktoikh. Regarding the church singer's work, the alphabetical index of the chants composed or adapted by George Ucenescu (54 chants) is offered, along with the index of songs distributed according to their authors. Interesting information about Ucenescu's activity as a folklorist and editor is integrated, thus continuing the chapter on that about Anton Pann, the complex musician who collected lay songs in the compilation Spitalul amorului sau cântătorului (1850-1852). Along the same line, Ucenescu compiled the manuscript Carte de cântări cu note psaltichie, which contains "567 of songs", many of which were taken from his mentor's collection, while other pieces (Christmas carols, songs about the star, songs from children's folklore) - were collected from his students and then "adjusted" after the fashion of the time.

In the final sections of his $\mathrm{PhD}$ thesis Muzica de tradiție bizantină. Șcheii Brașovului, Constantin Catrina reviews the psalm chanting manuscripts at the Library of the Museum within the Church in Șcheii Brașovului, the "George Bariţiu” County Library, and Romanian and bilingual manuscripts on psalm chanting extant in other localities in Romania, as well as at Mount Athos (Greece). Basic codicological data basic are offered, as well as a summary of some theoretical and morphological aspects extracted from the manuscripts he studied. Information on upgrading the church chant by introducing harmonic choir singing and the connection of theological education in the Brasov area to contemporary trends and ideas conclude Constantin Catrina's exceptional thesis; with the experienced historian's eye, he managed to capture the finest and most relevant details of the evolution of the psalm chanting school from Scheii Brasovului, whose activity was closely linked to that of the other major centres in the Romanian Principalities. 
Constantin Catrina further important achievement in the field of musical Byzantinology is his volume Ipostaze ale muzicii byzantine/Aspects of byzantine music, published in 2004, at the prestigious Publishing house Editura Muzicală in Bucharest. The author's opinion on the volume is as follows: "my book brings to the fore important personalities from the world of Byzantine music. I have presented in a few pages the personality and the creation of Ioan sin Radu Duma Braşoveanul, then I discussed Ilie Fotino, also Nicolae Brătescu and his six manuscripts at Şcheii Braşovului, Ilie Stoianovici, George Ucenescu and Oprea Demetrescu Anton Pann's students. [...] in this book I have tried to develop, to connect, Byzantine music in Transylvania and its affinities with various cultural centres in the country, such as Iaşi, Buzău, Târgovişte, Curtea de Argeş, Craiova, Putna, Neamţ, Cluj. By emphasizing these links in the pages of the book, I have finally come to the conclusion that the national unity of the musical culture of Byzantine tradition in the last three or four hundred years” is undeniable. (Chircev, 2004, p. 8). Therefore, part of the topics of this volume The School from Scheii Brasovului are continued and further explored in Ipostaze ale muzicii bizantine. Using the technique of the interview, the author also creates a very useful approach of the contemporary world, by outlining portraits of famous Byzantinologists who established their reputation as professors and researchers or composers: Titus Moisescu, Sebastian Barbu Bucur, Dragos Alexandrescu, Alexie Buzera, Vasile Vasile, Vasile Grăjdian, Doru Popovici.

\section{The activity in the field of folklore collection and research - Constantin Catrina's lifetime passion}

His achievements in the field of collecting folklore were constant and noticeable throughout his entire career: he collected material and published volumes, collaborated and authored volumes, and published an impressive number of papers in ethnology, in literary and musical folklore. Also, his effort in collecting folklore during field trips ended with praise worthy results: he collected and transcribed around 2000 folk songs. His activity as a conductor, composer of adapted choral folklore, and as artistic manager has been particularly appreciated; this shows in the fact that, for almost two decades, he held important positions in institutions involved in the creation and preservation of the folk traditions of Brasov county (Deaconu, 2008, pp. 15516, 21-36).

I will briefly point out only one of his remarkable achievements in folklore - his last one, the volume Tezaur de etnografie și folclor in județele Covasna și Harghita (2013, Sfântu Gheorghe: Eurocarpatica, in collaboration with Nicolae Bucur, PhD.). The author did not live to see the day when the volume was released, but it was peer-reviewed posthumously in the final section of the volume In memoriam dedicated to the anniversary of Constantin 
Catrina (Lăcătuşu, 2013) by one of his friends and collaborators, Byzantinologist and ethnomusicologist Constantin Secară. According to the latter, the volume "brings together the most important studies on the musical and literary folklore, the culture and spirituality, and, perhaps most importantly, the testimony of the existence and vitality of the Romanians in the areas they have inhabited in the course of their history .” (Secară, 2013, p. 512) Constantin Catrina authored 12 of the studies in this volume; the studies had various topics: historiography - George Bariţiu about issues of art creation in 19th century Transylvania, Issues related to ethnography and folk art in the the magazine "Transylvania"; Folklorists as and musical folklore in the Covasna county. A Historical Outlook; a bio-bibliografic contribution - personalities from Covasna with an important role in "enriching the Romanian heritage in South-Eastern Transylvania” (Secară, 2013, p. 513); ethno-musicological: Notes on several collections of musical folklore in the Covasna county, and Remarks on the pastoral customs and poetic-musical creations from Southeastern Transylvania (the Land of Bârsa and Covasna. Circulation and strafication. In these studies, the author aimed at "investigating the musical phenomenon in the past ages from a diachronic-historic perspective" (Lăcătuşu, 2013, p. 512) in the specified area. In the paper mentioned, Constantin Catrină and Nicolae Bucur, PhD., offer, at the same time, an extensive bibliography, particularly useful for future research. The volume Tezaur de etnografie și folclor in județele Covasna și Harghita represents the highest point in Constantin Catrina's meritorious life-long efforts devoted to folklore as a diligent and prolific researcher.

\section{Conclusions}

A complex personality, with multifarious concerns in research as well as in composition, Constantin Catrina (1933-2013) was active as a folklorist, historian, musicologist, Byzantinologist, composer; he dedicated his entire life to the research of the Romanian music, viewed in all its manifold manifestations: folklore music, Orthodox church music of the Byzantine tradition as well as lay music. His investigations were directed mainly towards the area of Brasov and its surroundings. He diligently studied documents about the musical life of the city in archives and libraries, discovered interesting information about the cultural personalities of this old Transylvanian city, with rich cultural traditions and diverse influences. He also managed to reveal their connections with other cultural centres in Romania. He was a pioneer in the field of Byzantinology, filling a space left empty in the history of Byzantine music by emphasizing the activity of an important centre of church music teaching and education in central Transylvania - the School of "Saint Nicholas” Church in Șcheii Brasovului between the 15th and 20th centuries. In terms of folklore research, he investigated the areas related to Brasov and 
collected a rich ethnographic, literary and musical material which he published in reputable collections. In all three lines of activity, he wrote and published an impressive number of articles in the local and specialised national press, thus proving to have a genuine passion for research and for the dissemination of its results to the specialists and the general public.

Beyond his professional career, with scientific results acknowledged and appreciated by his peers, Constantin Catrina the man remains in the memory of those who knew him as a generous great hearted person, broad minded, modest; such qualities are seldom found even in the most elevated environments. Evidence to that are the portraits included in the volume that was dedicated to him on his 80th anniversary; words of sincere and warm appreciation are used to describe him, a unanimous gratitude of friends, colleagues and close collaborators emerges from their contributions. As Byzantinologist Elena Chircev mentioned in the portrait that she dedicated to Constantin Catrina on his 75th anniversary, he remains in our memory as an "informed interlocutor in Byzantinology and ethnology, an avid researcher and devoted mentor to younger collaborators, a generous friend to all who had the chance to meet him and to appreciate together the beauty of a psalm chanting manuscript, a peasant's suit or an ancient folk song” (Chircev, 2008, p. 8).

\section{References}

Catrina, C. (1994). Studii și documente de muzică românească, vol. II. București; Editura Muzicală.

Catrina, C. (2001). Muzica de tradiție bizantină. Șcheii Brașovului [The music of Byzantine tradition. Șcheii Brașovului]. Braşov: Editura Arania.

Catrina, C. (2003). Ipostaze ale muzicii de tradiție bizantină din România [Aspects of byzantine music]. București: Editura Muzicală.

Catrina, C. (2005, Ed.). Sebastian Barbu-Bucur - 75 de ani. București: Editura SemnE.

Catrina, C. (2009). Pr. Gh. N. Dumitrescu-Bistrița și revista „Izvorașul”. RâmnicuVâlcea: Editura Fântâna lui Manole.

Chircev, E. (2003). Portret la 70 de ani - Constantin Catrina. Renașterea, 11 (165), noiembrie, 7. Cluj Napoca: Arhiepiscopia Ortodoxă a Vadului, Feleacului și Clujului.

Chircev, E. (2004). Să ne preocupăm de muzica credinţei noastre. Interviu cu prof univ. dr. Constantin Catrina. Renașterea, 11 (177), noiembrie, 8. Cluj Napoca: Arhiepiscopia Ortodoxă a Vadului, Feleacului și Clujului.

Chircev, E. (2008). Privitor în oglinda timpului - Constantin Catrina la 75 de ani. Intermezzo, 2, decembrie, 86. Cluj Napoca: Academia de Muzică „Gheorghe Dima”. 
Deaconu, G. (2008, Ed.). Constantin Catrina privitor în oglinda timpului. RâmnicuVâlcea: Editura Fântâna lui Manole.

Ionescu, G.C. (2003). Muzica Bizantină în România. Dicționar Cronologic. București: Editura Sagittarius.

Jompan, D. (2015). Constantin Catrina și Braşovul muzical enciclopedic. 7 zile. Ziarul gugulanilor, la Caransebeș. Retrieved from http://www.7zile.com/2015/11/12/constantin-catrina-si-brasovul-muzical-enciclopedic/

Lăcătușu, I. (2013, Ed.). Constantin Catrina - 80 de ani. Sfântu-Gheorghe: Eurocarpatica; Braşov: Mecatrin.

Secară, C. (2013). Gânduri la despărțirea de Constantin Catrina. In Lăcătușu, I. (Ed.). Constantin Catrina - 80 de ani (pp. 511-514). Sfântu-Gheorghe: Eurocarpatica; Braşov: Mecatrin. 